\title{
Indonesian Students Adaptation in Dutch Universities
}

\author{
Meidiati Sekarsari \\ Department of Economy, YARSI UNIVERSITY, Jakarta \\ E-mail: meidiati.sekarsari@yarsi.ac.id
}

\begin{abstract}
KATA KUNCI Indonesian International Students, Sociocultural adjustment, Independent SelfConstrual, English Self-Confidence
\end{abstract}

ABSTRAK Hidup di lingkungan baru tidaklah mudah bagi mahasiswa internasional. Selama proses penyesuaian diri di kehidupan barunya, para mahasiswa ini menghadapi berbagai tekanan interpersonal dan menunjukkan kesulitan selama masa belajar. Dalam upaya memprediksikan kesuksesan dan kepuasan mahasiswa internasional, maka diperlukan usaha untuk melihat proses penyesuaian dirinya. Pengaruh dari bagaimana seseorang melihat dirinya dan juga kepercayaan diri dalam berbahasa Inggris, diprediksi memberikan kontribusi pada penyesuaian sociocultural mahasiswa internasional ini. Dalam penelitian ini, independent selfconstrual dan English self-confidence dari 138 mahasiswa Indonesia yang berkuliah di Belanda diteliti sebagai faktor-faktor yang mungkin mempengaruhi penyesuaian sociocultural-nya. Hasil penelitian menunjukkan bahwa mahasiswa Indonesia ini mengalami kesulitan sociocultural yang lebih rendah ketika mereka memiliki independent self-construal dan kepercayaan diri berbahasa Inggris yang lebih tinggi. Kepercayaan diri berbahasa Inggris ini juga bertindak sebagai mediator dalam hubungan antara independent self-construal dan kesulitan sociocultural. Terakhir, ketika semua faktor dianalisis menggunakan multiple regression analysis, ditemukan bahwa lama tinggal dan dua dimensi dari independent self-construal (autonomy dan uniqueness) memiliki pengaruh paling signifikan terhadap kesulitan sociocultural.

\section{INTRODUCTION}

In order to achieve a better life, many students strive for higher educational background in various wellknown universities in all around the world, mostly in the industrialized countries of North America, Europe and Australia (Yang et al., 2006). However, living in a new country is not easy for most international students. In their process of adapting new environment, many of these international students experience some difficulties in various levels and situations which may hinder then in the process of adaptation and pursuing their education. As they come to the new environment, the new international students are confronted with various information about the new life styles and pattern of behaviors.
Therefore, they have to learn different ways of thinking and behaving which are more suitable with the new environment. Moreover, as the result of cultural changes (e.g., language difficulties, loss of similar friends and families and the need to learn more appropriate skill and academic behavior), the international students may experience psychological stress or "culture shock" (Bourne et al., cited in Cross 1995).

Many scholars believe that the cultural changes from the origin culture to the host country's culture may lead to greater interpersonal stressor and adjustment difficulties to get involved in daily life and campus activities (Kaczmarek et al., 1994; Ingman, 1999) 
and continue to express feeling of stress and vulnerability throughout their time of study (Ingman, 1999). Therefore, it is important to understand the experiences of cross-cultural adaptation especially to predict both of the success and satisfaction within sojourn and also the quality of relations between members from different cultural groups (Yang et al., 2006). Ward and Kennedy, 1999) conceptualized the cross-cultural adjustment into two conceptually distinct but empirically related dimensions: psychological (emotional/affective) and sociocultural (behavioral) adjustment. The psychological adjustment stresses the emotional well-being and satisfaction with sojourning experiences, while the sociocultural adjustment emphasizes the ability to "fit in" and the skill to deal with interactive aspects of host cultural context (Yang et al., 2006).

One of the possible factors that might affect international students' crosscultural adjustment is the self-construal of the individual (Yang et al., 2006). Markus and Kitayama (1991) defined the self-construal as the degree to which people view themselves as separated from (Independent self-construal) or connected with (Interdependent selfconstrual) others. The independent sense of self is believed as the characteristic of individual from Euro-American culture, where the self is viewed as a whole, unique and autonomous entity that is distinct from others. On the other hand, the

Interdependent self-construal individuals view themselves as part of an encompassing social relationship (Wang, 2009). In this sense of self, individuals are more connected and less differentiated from others. The interdependent self-construal is the characteristic of individual from Asia and Africa.

As part of Asian nation, Indonesian people are believed to view themselves in more interdependent way. So, it is likely for Indonesian international students in the Netherlands to face more difficulties in the crosscultural adjustment since individuals in the host country perceive themselves in more independent way. Therefore, in the process of cross-cultural adjustment, it is important for Indonesian international students to have more independent selfconstrual which represents the prototypical type of self in individualist country like the Netherlands, thus they might face less difficulties in fitting with the new environment.

With those rationales, the relationship between independent selfconstrual and the sociocultural adjustment will be investigated.

Proposition 1: Independent self-construal is predicted to have negative correlation with the sociocultural difficulties on Indonesian international students who are studying in the Netherlands.

Besides the sense of self, communication skill and confidence in using English as second language are essential for satisfying everyday needs and hence attaining a sense of well-being in cross-cultural adjustment (Clement et al., 1996; Yang et al., 2006). Higher confidence in using English as the second language enables international students to have more courage in practicing their language fluency and proficiency, which leads to effectiveness in communication. Moreover, with more confidence in using English, the international students are expected to have fewer difficulties in daily life, which lead to better adjustment.

Proposition 2: English self-confidence is predicted to have negative association with the sociocultural difficulties on Indonesian international students who pursuing their education in the Netherlands.

Besides predict the sociocultural adjustment directly, the English self- 
confidence also predicted to act as a mediator in influencing the relation between independent self-construal and sociocultural difficulties (Wang, 2009). The result of study conducted by Yang et al. (2006) found that independent self construal directly predict English selfconfidence, while Yamaguchi and Wiseman (2001) concluded that independent self-construal is associated with greater communication effectiveness and lead to better cross-cultural adjustment. Therefore it is believed that the English self-confidence might act as mediator in the relationship between independent self-construal and the sociocultural difficulties.

Proposition 3: The relation between independent self-construal and sociocultural adjustment is predicted to have English self-confidence as a

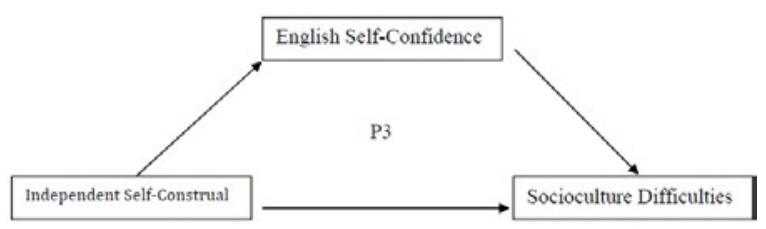

mediator.

The present study integrates these two possible factors that might affect the international students' cross-cultural adjustment: the independent selfconstrual (and its four sub-dimensions) and English self-confidence. It is believed that one factor impacts sociocultural adjustment more directly than the other variables. Therefore it is also important to look more carefully which variables become the real predictor of sociocultural adjustment as seen from all the possible predictor.

Proposition 4: Both independent (and its four sub-dimensions) and English selfconfidence will predict sociocultural adjustment on Indonesian international students in the Netherlands.

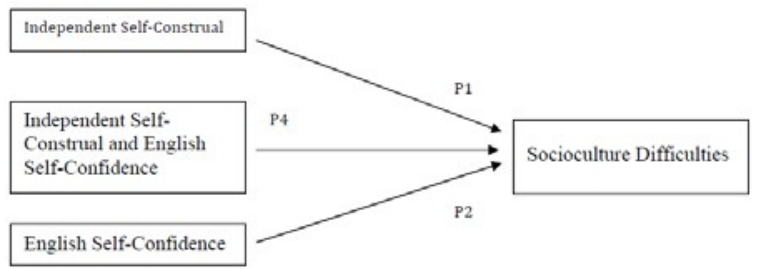

\section{METHODS}

This research was conducted through quantitative research approach with a structured data collection (survey) for the data collection process. The 4 sets of questionnaires are presented in 5-point Likert like scale. These questionnaires were made to measure the independent and dependent variables in this research, which are the independent self-construal, English self-confidence, sociocultural difficulties and additional demographic data.

In the first part of questionnaire, the Indonesian international students were asked to fill their demographic information, which are age, gender, educational program in the Dutch university, length of residency in the Netherlands, their ability to speak Dutch (novice, basic or fluent) and the number of international friends that they have at that time. English language confidence and English anxiety scale made by Clement and Baker (2001) were applied, simplified and modified to measure respondent's self-perception of confidence in using English. The final version had 5 items in total, with a high internal reliability of the Cronbach's alpha $(\alpha=.94)$.

The items in the self-construal measurement adopted from various SelfConstrual Scales and were modified by Wang (2009). In this research, the researcher only used 15 items of the Independent Self-construal which consists of four sub-dimensions of independent self-construal (i.e., autonomy, direct communication, uniqueness, and competition). The higher the score in this scale, the more they perceived themselves in an independent way. Ward and Kennedy's (1999) Sociocultural Adaptation Scale was modified into 15 items (originally has 22 items). The scale measures participants' experiences about the social difficulties 
level in various areas on daily life basis. This modified version reported high internal reliability ranging from .84 to 91 .

The target respondents are Indonesian international students who are pursuing their educational program in the Netherlands. Among 1250 Indonesian international students in the Netherlands (Nuffic, 2010), around 125 students are expected to participate in this research. The final result of the data collection process showed 173 respondents answering the survey, but only 138 responses are valid for further analysis. The remaining 35 responses have been excluded because of incomplete questionnaires. After finishing the process of collecting the data, the collected information were coded and then analyzed with two statistical methods (correlation and multiple regression analysis).

A set of hierarchical multiple regression analysis were conducted to examine the relative contribution of all predictive variable (independent selfconstrual and English self-confidence) to the outcome variable that is the sociocultural adjustment. This method is conducted to test the hypothesis 3 regarding the distinctive factors that contribute to the sociocultural adjustment. There are 3 steps of data entry in doing the hierarchical multiple regression analysis. Since respondents differed in their length of residence in the Netherlands, this variable was input first. Then the Independent Self-Construal variable (with its four sub dimensions) and the English Self-Confidence, were input in the second and third step.

To test the mediating effects of hypothesis 4 (if self-confidence in English mediates the relation between independent self-construal and sociocultural adjustment), the researcher did the same as Wang (2009) to utilize the procedures suggested by Baron and
Kenny (1986): a) regressing the mediator (English self-confidence) on the independent variable (independent selfconstrual); b) regressing the dependent variable (sociocultural adjustment) on the independent variable (independent selfconstrual); c) regressing the dependent variable (sociocultural adjustment) on the mediator; d) regressing the dependent variable (sociocultural adjustment) on both the independent variable (independent self-construal) and mediator variable (self-confidence in English).

\section{RESULT AND ANALYSIS}

\section{Descriptive Analysis}

The result of descriptive analysis of the sample study is shown on the table below.

\begin{tabular}{|c|c|c|c|}
\hline & & $\mathrm{N}=138$ & $\begin{array}{l}\text { Percentage in } \\
\text { sample }\end{array}$ \\
\hline \multirow[t]{2}{*}{ Gender } & Male & 67 & $48.6 \%$ \\
\hline & Female & 71 & $\mathbf{5 1 . 4} \%$ \\
\hline \multirow[t]{4}{*}{ Age } & $\leq \mathbf{2 0}$ & 16 & $11.6 \%$ \\
\hline & $21-25$ & 55 & $39.9 \%$ \\
\hline & $26-30$ & 48 & $34.8 \%$ \\
\hline & $>\mathbf{3 0}$ & 19 & $13.7 \%$ \\
\hline \multirow[t]{3}{*}{ Education program } & Bachelor & 25 & $18.2 \%$ \\
\hline & Master & 95 & $68.8 \%$ \\
\hline & Doctoral & 18 & $13 \%$ \\
\hline \multirow[t]{5}{*}{ Length of Residence } & $\leq 6$ months & 24 & $17.4 \%$ \\
\hline & 7-12 months & 69 & $50 \%$ \\
\hline & 1-2 years & 25 & $18.1 \%$ \\
\hline & $2-5$ years & 15 & $10.9 \%$ \\
\hline & $>5$ years & 5 & $3.6 \%$ \\
\hline \multirow[t]{3}{*}{ Speak Dutch } & No & 76 & $\mathbf{5 5 . 1} \%$ \\
\hline & Little & 48 & $34.8 \%$ \\
\hline & Yes & 14 & $10.1 \%$ \\
\hline Number of Int1' & $<5$ & 48 & $34.8 \%$ \\
\hline \multicolumn{4}{|l|}{ Friend } \\
\hline & $5-10$ & 54 & $39.1 \%$ \\
\hline & $10-20$ & 23 & $16.7 \%$ \\
\hline & $>\mathbf{2 0}$ & 13 & $9.4 \%$ \\
\hline
\end{tabular}


From the sample, the number of males and females are considerably equal. Most of the respondents are ranged between 21-25 years old (39.9\%) and 25-30 years old $(34.8 \%)$. It is understandable since most of them are taking the master program in their universities $(68.8 \%)$. From total sample of 138 respondents, 69 of them $(50 \%)$ have been in the Netherlands for 7 months to 1 year. However, only 14 persons $(10.1 \%)$ of them are able to speak Dutch fluently. Lastly, based on the interaction of Indonesian international students with other international students, most of them (102 person) only have less than 10 international students who spend leisure time together with them.

\section{Reliability of the Scale}

The result of the reliability of the scales showed that all the scales used in this study demonstrated strong reliability: English self-confidence Scale (Alpha = .836), Independent self-construal Scale $($ Alpha $=.755)$, and the Social Difficulty Scale $($ Alpha $=.822)$.

\section{Effects of Demographic Variables}

There are six demographic variables in this study: gender, age, education program in the Netherland (Bachelor, Master or Doctoral), length of residence in the Netherlands, ability to speak Dutch and number of international friends that they have. To examine whether these variables have any correlation with sociocultural difficulties, the Pearson correlations were carried out.

The results showed that the length of residence in the Netherlands $(M=$ 17.5months,

$S D=16.3$ ) was significantly associated with sociocultural difficulties $(r=-.248$, $p<.01)$. Besides the length of residence in the Netherlands, the ability to speak Dutch and the number of international friends they have also had significant correlation with sociocultural difficulties $(r=-.177, p<.05$ and $r=-.294, p<.01$ consecutively). The other three variables (gender, age, and education program in the Netherlands) did not reveal any significant correlation with sociocultural difficulties as the outcome variable in this study.

Another significant correlation was shown in the relation of student's capability to speak Dutch and the number of international friends they have associated with the English selfconfidence ( $r=.320, p<.01 ; r=185, p<$ .05 respectively). As with the Independent self-construal, the only demographic variable that has significant correlation with is the number of international friends they have $(r=.296$, $p<.01)$.

\section{Testing of Propositions}

As the broad scale, the independent self-construal has significant correlation with the sociocultural adjustment at significant level of 0.01 with -.340 . The negative correlation shows that the higher the independent self-construal score students have, the lower the sociocultural difficulties they perceived, which means the better the sociocultural adjustment they have in the Netherlands. It means that the proposition 1 is empirically proved.

\begin{tabular}{|c|r|}
\hline & $\begin{array}{c}\text { Sociocultural } \\
\text { Difficulties }\end{array}$ \\
\hline Independent Self-Construal & $-.340^{* *}$ \\
\hline Autonomy & $-.375^{* *}$ \\
\hline Direct Communication & $-.266^{* *}$ \\
\hline Uniqueness & $-.381^{* *}$ \\
\hline Competition & .052 \\
\hline English Self-Confidence & $-.286^{* *}$ \\
\hline
\end{tabular}

Note: **. Correlation is significant at the 0.01 level (2tailed).

The results of correlation between the four sub dimensions of independent self-construal and the sociocultural adjustment showed that the subdimension competition had insignificant correlation $(p<0.54)$. While the other 
three sub-dimensions autonomy, direct communication and uniqueness all showed significant correlation at the 0.01 level of significant with -.375, -.266 and .281 respectively.

The result of correlation Bivariate Pearson between the English selfconfidence and the Sociocultural difficulties is $-.286^{* *}$. This number showed that the two variables have low negative correlation, which is significant at 0.01 level (2-tailed). It means that the higher the English self-confidence those students have, the lower the sociocultural difficulties they experienced, therefore the proposition 2 is accepted.

In order to test the proposition 3, a series of regression analysis were conducted to test the existence of mediating effect. The result showed that the original direct relationship of independent self-construal on socioculture difficulties $(\beta=-.340, \mathrm{p}<$ 0.01 ) was reduced to $-.261, \mathrm{p}<0.01$ when English self-confidence was included in the regression analysis. It indicates that English self-confidence acted as mediator in the relation between independent self-construal and sociocultural adjustment.

In this case, the English selfconfidence is proved to become the mediator variable in the relationship between independent self-construal and the sociocultural difficulties since this variable fulfilled the three conditions to be considered as mediator. In the path a, the independent self-construal is proved to have significant (and negative) correlation toward the English selfconfidence with $-.546, \mathrm{p}<0.01$, while the English self-confidence also directly influence the student's sociocultural difficulties with -.286, $\mathrm{p}<0.01$ (path b). The original influence of independent self-construal toward the sociocultural difficulties was reduced significantly after the English self-confidence was taken into account (from -.340 to -.261, both $\mathrm{p}<0.01)$. This significant reduction indicates that the given mediator (the English self-confidence) is indeed potent, although not both necessary and a sufficient condition for an effect to occur (Baron and Kenny, 1986). It means that the proposition 3 is confirmed, since the English self-confidence had partial mediating effect on the relationship between the independent self-construal and the sociocultural difficulties.

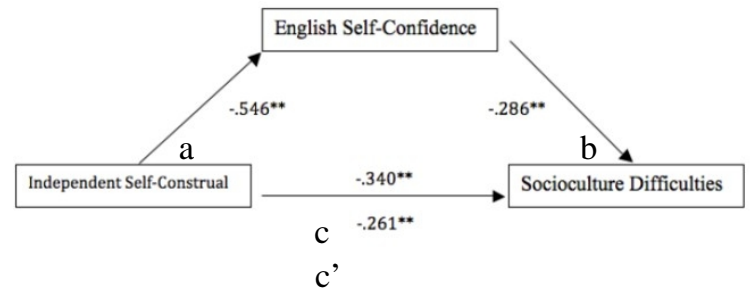

Lastly, to examine the contribution of various predictive variables toward the sociocultural adjustment, a series of hierarchical multiple regression analysis was conducted. In this study, the length of residence of Indonesian international students in the Netherlands was proved to have significant contribution to their sociocultural adjustment, so that this variable was input in the first step. After the length of residence, the three subdimensions of independent self-construal were added (autonomy, direct communication, and uniqueness). The sub dimension competition was not added to this hierarchical multiple regression analysis since this variable insignificantly correlate with the sociocultural adjustment. Finally the English selfconfidence variable was taken into account as the last predictor of sociocultural adjustment.

This table below are the result of the hierarchical multiple regression analysis. The $\mathrm{R}^{2}$ column showed how much of the variability in the outcome is accounted for by the predictors. While the F-ratio represents the ratio of the improvement in prediction that results 
from fitting the model, relative to the inaccuracy that still exists in the model (Field, 2009). When only the length of residence was taken into account, this variable gave only $\mathrm{R}^{2}=.061, \mathrm{~F}=8.9, \mathrm{p}<$ .02 of the variation in the sociocultural adjustment. However, this value highly increased to $\mathrm{R}^{2}=.263, \mathrm{~F}=11.8, \mathrm{p}<.001$ after the second variables (the three sub dimensions of Independent selfconstrual) were added into the model. Finally this variation did not show any significant addition after the last variable, English self-confidence was entered $\left(\mathrm{R}^{2}=\right.$ $.264, \mathrm{~F}=9.5, \mathrm{p}<.001)$.

Throughout the hierarchical multiple analyses, the length of residence and the two sub-dimension of independent self-construal (autonomy and uniqueness) had significant influence while the direct communication and the

\begin{tabular}{|c|c|c|c|c|c|c|}
\hline Step & Independent Variable & $\mathrm{R}^{2}$ & $\Delta \mathrm{R}^{2}$ & $\mathrm{~F}$ & B & $\beta$ \\
\hline 1. & Length of Residence & .061 & $-\cdot$ & $8.9^{* *}$ & -.109 & $-.248^{* *}$ \\
\hline \multirow[t]{6}{*}{2.} & & .263 & .202 & $11.8^{* * *}$ & & \\
\hline & Length of Residence & & & & -.109 & $-.246^{* *}$ \\
\hline & Independent Self-Construal: & & & & & \\
\hline & Autonomy & & & & -.977 & $-.240^{*}$ \\
\hline & Direct Communication & & & & -.285 & -.094 \\
\hline & Uniqueness & & & & -.836 & $-.228^{* *}$ \\
\hline \multirow[t]{7}{*}{3.} & & .264 & .001 & $9.5^{* * *}$ & & \\
\hline & Length of Residence & & & & -.106 & $-.241^{* *}$ \\
\hline & Independent Self-Construal & & & & & \\
\hline & Autonomy & & & & -.915 & $-224^{*}$ \\
\hline & Direct Communication & & & & -.264 & -.088 \\
\hline & Uniqueness & & & & -.823 & $-.224^{*}$ \\
\hline & English Self-Confidence & & & & -.122 & -.04 \\
\hline
\end{tabular}

English self-confidence did not have any significant correlation.

\section{DISCUSSION}

\section{Effect of Demographic Variables}

First, the length of residence in the Netherlands was found to have significant influence to the sociocultural difficulties $(r=-.248, p<.01)$. The negative correlation means that the longer students stay in the Netherlands, leads to the fewer sociocultural difficulties they faced or the better sociocultural adjustment they experienced. Moreover, from the hierarchical multiple regression analysis, the length of residence was proved to be a significant predictor for the sociocultural adjustment. This finding is consistent with several previous studies like from Liu (1985), Ward and Kennedy (1993) or from Yang et al. (2006), which also found an increase in adjustment with greater time in the host country. The host country as new environment might have very different culture and way of life that students have in the original country, however the length of time helps them to adjust to the new environment both psychologically and socioculturally (Wang, 2009). Therefore, the longer they stay in the new cultural environment, the more they become used to the cultural norm, way of live, and climate in the host country, thus the cultural shock that might be experienced in the initial stage of arrival would decrease. As they had to overcome the daily activities with the host country or the second language, they become more socially and linguistically competent along with their settlement in the host country.

The Netherlands has its own language as their mother language, which is Dutch. Even so, English, as their second language is very well known in this country. The international students who have English as their second language do not enforced themselves to be competent in Dutch (which means the third language for them) since in the academic setting all the education activities are carried out in English. However, if they are capable to speak Dutch, this additional point might give them an extra ability to adjust better in the Netherlands. Although there might be no previous research for this study, but 
the result of this study has shown a significant influence of this variable.

$$
\text { Lastly, the number of }
$$

international friend also proved to have a significant correlation with the sociocultural adjustment. The more students have international friends form other country (especially from the host country), the better sociocultural adjustment they faced, looked by the fewer sociocultural difficulties they perceived. This result is consistent with previous research by Surdam and Collins (1984), which is demonstrated that international students who spend more of their leisure time with American students (host nations) are significantly better adapted than those who spend more leisure time with their fellow international students from same country. To have more international friends (more specifically friends from host nations) means that the international students have higher chance to learn more the way of living in the host country, how they can interact one another, how they can behave in certain situation and in the end leads to a better understanding and better adjustment of their social life. It is generally believed that friendship with host country nationals provide international students with opportunity to learn more about the culture, to gain practical information, and to develop social skills (Furnham \& Alibhai cited Cross, 1995).

\section{Self-construal and Socioculural Adjustment}

In this study, the first set of the research hypothesis was regarding the correlation between self-construal (focused more on the independent selfconstrual) and the sociocultural adjustment. As expected before, there are a strong but negative association between independent self-construal and the sociocultural difficulties. Means the higher Indonesian international students view themselves as independent self, the fewer they perceived the sociocultural difficulties, which lead to a better sociocultural adjustment.

Looking through the four sub dimensions of the independent selfconstrual, the sub-dimension competition was the only sub dimension that did not show any significant relation with the international students' sociocultural adjustment. The other three sub dimensions were significantly correlated with the sociocultural adjustment. As Ward and Kennedy (2003) argued, the sociocultural adjustment is derived from the social/cognitive models and stresses the ability to "fit in" and the skill to deal with interactive aspects of host cultural context. The sub-dimension autonomy and uniqueness are derived from the characteristics of individualistic culture, therefore higher score in that subdimension part lead to better sociocultural adjustment. In 1995, Cross explained more than a very individualistic American classroom, in which standing out and demonstrating one's uniqueness may be necessary for achieving success. In contrast, this condition might be frustrating for students with low independent self-view.

While for the sub-dimension direct communication, this is also one of the characteristics of individualistic country. Moreover, Hall (1976) stated that being direct is one of the major characteristics of low-context communication (typically of the individualistic culture). As sociocultural adjustment involves the ability to "fit in" the host culture's way of doing things, being direct might have work as a social skill that helps students to cope and deal with social situation in the way host nationals do and thus promoted their adjustment (Oguri and Gudykunst, 2002). In other words, the more students use communication behaviors that are appropriate in the host nationals, the 
more they are able to communicate effectively with host nationals, and the greater their sociocultural adjustment (Oguri and Gudykunst, 2002).

\section{English Self-Confidence and the Sociocultural Adjustment}

The second hypothesis in this study was regarding the relation between the English self-confidence and the sociocultural adjustment. As expected before, the result has shown that English self-confidence had significant correlation with the sociocultural adjustment $(r=-.286, p<0.01)$. This means that the more students feel confidence in using English as their second language, the better they are able to adapt into the host culture, since the fewer sociocultural difficulties they faced. Cited from Wang (2009), several results were found in the previous studies like from Duru and Poyrazli (2007), Noels, Pon and Clement (1996), or Yeh and Inose (2003). From the result, it can be concluded that English proficiency and self-confidence directly influence Asian international students' sociocultural adjustment in the Western countries, as higher confidence in using English as second language facilitates students to enhance their language ability and fluency and also the communication effectiveness due to more practice time they have in their daily life. In the end, the effectiveness in using English in variety of daily activities enables students to have more successful cultural adaptation.

English Self-Confidence as the Mediating Variable between Independent SelfConstrual and the Sociocultural Adjustment

The last hypothesis in this study is regarding the role of English selfconfidence as mediating variable between the independent self-construal and the sociocultural adjustment. In 2009, Wang proposed that English self-confidence might be a mediator between the other two variables. This argument derived from the previous studies from Yamaguchi and Wiseman (2001) and Yang et al. (2006) that proved the direct influence of independent self-construal on English self-confidence, and the fact that English self-confidence is one predictor of cross-cultural adjustment (Wang, 2009). Similar with Wang's result study (2009), the result of this research also support the hypothesis. The direct impact of independent selfconstrual on the sociocultural adjustment was greatly reduced when the English self-confidence was added in the regression model. This phenomenon was explained by Wang (2009) as the indication of pivotal role of the English usage.

\section{CONCLUSION}

This study has examined the effect of Independent self-construal and English self-confidence on the cross cultural adjustment of Indonesian students who are studying in the Dutch universities. The result of this study has shown that independent self-construal and English self-confidence are predictors for the sociocultural adjustment of Indonesian students when calculated partially. More specifically, only the sub-dimension competition from four sub dimensions of independent selfconstrual that did not have any significant correlation to the sociocultural adjustment. The other three sub dimensions (autonomy, direct communication, and uniqueness) are showing the significant yet negative correlation toward the sociocultural difficulties. However, when all the possible factors were analyzed using Hierarchical Multiple Regression Analyses, the English self-confidence and sub-dimension direct communication did 
not show any significant correlation. Therefore, the remaining two subdimension of independent self-construal (autonomy and uniqueness) and additional demographic variable (the length of residence) become the distinctive factors that contribute to the sociocultural adjustment. Another interesting result came from the English self-confidence variable. From this study, it was proved that besides directly influenced students' sociocultural adjustment, English self-confidence also becomes a mediator in the relation between independent self-construal and the English self-confidence.

\section{BIBLIOGRAPHY}

Baron, R. M., \& Kenny, D. A. (1986). The moderator-mediator variable distinction in social psychology research: Conceptual, strategic, and statistical considerations. Journal of Personality and Social Psychology, 51, 1173-1182.

Clement, R. (1980). Ethnicity, contact and communicative competence in and second language. In $\mathrm{H}$. Giles, W. P. Robinson, \& P. M. Smith (Eds.), Language: Social Psychological Perspectives (pp. 147-154). Oxford: Pergamon Press.

Cross, S. E. (1995). Self-construals, coping, and stress in cross-cultural adaptation. Journal of CrossCultural Psychology, 26, 673-697.

Ingman, K. A., (1999). An Examination of Social Anxiety, Social Skills, Social Adjustment, and SelfConstrual in Chinese and America Students at an American University. Doctoral Dissertation, Virginia Polytechnic Institute and State University.

Markus, H. R., \& Kitayama, S. (1991). Culture and the self: Implications for cognition, emotions, and emotion. Psychological Review, 98, 244-253.

Noels, K. A., \& Clement, R. (1996). Communicating across cultures: Social determinants and acculturative consequence. Canadian Journal of Behavioral Science, 28, 214-228.

Noels, K. A., Pon, G., \& Clement, R. (1996). Language, identity, and adjustment: The role of linguistic self-confidence in the acculturation process. Journal of Language and Social Psychology, 15, 246-264.

Nuffic, Netherland organization for international cooperation in higher education (2010). Mapping mobility in 2010. International Mobility in Dutch Higher Education.

Oguri, M. \& Gudykunst, W. B. (2002). The influence of self-construals and communication styles on sojourners' psychological and sociocultural adjustment. International Journal of Intercultural Relation, 26, 577593.

Singelis, T. M. (1994). The measurement of independent and interdependent self-construals. Journal of Personality and Social Psychology, 20, 580-591.

Singelis, T. M., Bond, M. H., Sharkey, W. F., \& Lai, C. (1999). Unpacking culture's influence on self-esteem and embarrassability. Journal of Cross-Cultural Psychology, 30 (3), 315-341.

Wang, W. H. (2009). Chinese International Students CrossCultural Adjustment in the U.S: The Roles of Acculturation Strategies, Self-Construal, Perceived Cultural Distance, and English Self-Confidence. 
Doctoral Dissertation, the University of Texas.

Ward, C., \& Kennedy, A. (1993a).

Psychological and socio-cultural adjustment during cross-cultural transitions: A comparison of secondary students overseas and at home. International Journal of Psychology, 28, 129-147.

Ward, C., \& Kennedy, A. (1999). The measurement of sociocultural adaptation. International Journal of Intercultural Relations, 18, 329-343.

Yamaguchi, Y. \& Wiseman, R. L. (2001).

Locus of control, self-construal, intercultural effectives, and crosscultural adjustment. Paper presented at the Annual Meeting of the International Communication Association, Washington, DC.

Yang, R. P., Noels, K. A., \& Saumure, K.

D. (2006). Multiple routes to crosscultural adaptation for international students: Mapping the paths between self-construal, English language confidence, and adjustment. International Journal of Intercultural Relations, 30, 487-506. 